\title{
Doctrine of "Caveat Emptor" (Buyer be aware) in Common Law and the Doctrine of "Khiyar al aib" (Option of defect) in Islamic Law: A Comparative Study
}

\author{
Abdul Malek $^{*}$ \\ Anju Man Ara Begum** \\ Kazi Arshadul Hoque
}

\begin{abstract}
The Sale of Goods Act, 1930 deals with one of the important branches of contract especially the moveable goods with which the general people in the world deal every day. In dealing with the goods proposed for sale must be free from any known or unknown defect of either party of the contract of sale. Regarding the sale of defective goods the buyer has some remedies against the default seller in both common law and Islamic law. In common law it is known as "Caveat Emptor" (Buyer be aware) and in Islamic law it is known as "Khiyar al aib" (Option of defect). It is the general rule that the buyer should have an opportunity to satisfy himself as to the quality of the goods for his particular purpose and in absence of any query or unskilled test by the buyer, the seller is not to be liable for anything. In this article efforts have been made to examine the rights and duties of buyer and seller in Common law and Islamic Law. An attempt has also been made to find out similarities and dissimilarities of both laws regarding caveat emptor. Thus the paper, through the analysis of both laws, tries to address the problems and solutions related to caveat emptor.
\end{abstract}




\section{Introduction:}

In commercial transaction it is the duty of every buyer to be careful while buying goods of his or her requirements and also the seller is under an obligation to allow the buyer to examine the goods prior to entering into contract. It is not mandatory for the seller to disclose every defect of his or her goods in absence of any inquiry or asking by the buyer. The buyer should examine the goods thoroughly for his expected purpose and while doing so if he or she makes a mistake and chooses defective goods or if the goods are not suitable for his or her purpose, he or she cannot accuse the seller or cannot shift his or her own fault on the shoulder of the seller. Such obligation and judgment of the buyer is known as "caveat emptor" (buyers beware).

The general principle of law in common law system is that it aids the vigilant and not the dormant. Therefore, if the buyer makes a bad choice without exercising the option of inspection, he must curse himself for his folly in absence of any material misrepresentation or fraud on the seller's part. The Latin term "caveat emptor" (buyers beware) gives the responsibility of any risk in the goods on the shoulder of buyer especially if he does not inspect the quality of the goods. In common law, section 16 of the Sale of Goods Act, 1930 is applicable in Bangladesh, India etc. "The seller is not bound to supply the goods which should be suit for any particular purpose or which should possess any particular quality. It is the buyer's duty to select the goods of this requirement. After conclusion of sale the purchaser cannot recover the price or damages from the seller."1

To protect purchasers' interest Islamic Law also provides a doctrine which is known in Islamic terminology Khiyar al Aaib (option of defect). The doctrine of option of defect in Islamic arena gives the buyer an option to rescind the contract of sale or recover the damages when such defect in goods decreases its normal market value or makes it unfit to meet the requirements expected of it. A purchaser party needs to be satisfied with an object of free from defects. This makes it clear that the seller is under an obligation to allow the buyer to examine the quality of goods and if any defect is found in the goods by the buyer, Islamic law grants an option to rescind or to continue with the agreement in Islamic law of transaction even after the conclusion of sale. "But when the seller gives to buyer an opportunity to examine the goods of its quality and the buyer takes possession of the goods in sale knowing after disclosing the defect, no option 
Doctrine of "Caveat Emptor" (Buyer be aware) in Common Law and the Doctrine of "Khiyar al aib" (Option of defect) in Islamic Law: A Comparative Study

remains to him (buyer), because when he thus purchases or takes possession of the article, it is evident that he assents to the defect". ${ }^{2}$ The article brings the similarities and dissimilarities of the doctrine of caveat emptor in statutory laws prevailing in our country and Islamic doctrine of Khiyar al aib and justifies which one protects purchaser's rights more in a contract of sale of goods.

\section{Caveat Emptor and Khiyar al aib: Its origin and developments}

When a buyer takes anything depending on his skill and judgment, he himself is responsible. It is based on the judgmental premise that once a buyer ratifies himself as the suitability of the product for him, he would subsequently have no right to reject the same. The rule of caveat emptor, as it prescribed at the time of its origin, was quite rigid.

\section{1: In common law:}

In contract of sale it is an obligatory duty on the seller's part to allow the buyer to examine the goods to be sold before entering into contract of sale. On the other hand, it is the buyer's duty to select the goods of his requirements. "It was for the buyer to make him acquainted with the quality and defects of the goods which he contemplated purchasing". ${ }^{3}$

The right of the buyer to examine the goods was originated in the case of Chandelor vs. Lopus in the early of $17^{\text {th }}$ century and later on developed by different cases. In $17^{\text {th }}$ century mutual rights and duties of the seller and the buyer were embodied in the case Chandelor vs. Lopus. ${ }^{4}$ The case Chandelor vs. Lopus demonstrates evolving notions of warranty, and the contract legal theory under the English common law specially the concept of caveat emptor. In this case the defendant (Chandelor) was a person who sold articles made of gold and had a special knowledge in precious stones. This defendant owned a stone which he affirmed to the plaintiff Lopus was a bezar stone and sold it to Lopus for 100 (one hundred) pound. Lopus subsequently found that the stone possessed no healing powers (the stone forms in animal's intestinal system and was believed to have magical healing properties) and sent Chandelor before the King's Bench. The court held that the quality of bezar which he had not expressly warranted was a risk which the buyer must assume and there was no fraud in selling the stone as a bezar, so long as the seller did not expressly warrant it to be one. The Exchequer court held that the buyer had no right to his money back, saying the bare affirmation that it was a bezar stone, 
without warrant it be so, was no cause of action. Before this case, the term caveat emptor was first used by Fitz Herbert in 1534 about the purchase of a horse stating "if he be tame and have been ridden upon, then caveat emptor". 5

In another case Laidlaw vs. Organ paved the way to come forward the doctrine of caveat emptor. The defendant Organ purchased 111 (one hundred and eleven) hogsheads of tobacco (111000 pounds) from the Laidlaw and Company on February 18, 1815 between 8 and 9 A.M. On the same day, news circulated that a peace treaty had been accepted between America and Britain, ending the war of 1812 and lifting a naval embargo that had drastically depressed the price of American tobacco by 30 to 50 percent. Organ was aware of the lifting of the embargo because his brother had informed him earlier in that morning but Laidlaw was not aware of the news. During the discussion of the contract Organ was asked if he was aware of any reason for the price to be higher; but Organ remained silent about the news of embargo lifting. The Chief Justice Marshall said, "However on the questions of whether Organ had an obligation to disclose the information he had obtained about the end of the war, the opinion declares that the plaintiff Laidlaw was not bound to communicate it to Organ where the means of intelligence are equally accessible to both parties".

\section{2: In Islamic Law:}

In Islamic context Khiyar al aib here khiyar means choice, option or exercise of power of choice, refusal or right of withdrawal. ${ }^{6}$ According to Joseph Schacht the right of option has been given to the parties to a sale as long as they have not separated. ${ }^{7}$ The buyer of a property can cancel the bargain even after the bargain of sale. It is narrated by Hakim Ibn Hizam, Prophet (sm) said, "The seller and buyer have the right to keep or return the goods so long as they have not parted or till they part; and if both the parties spoke the truth and described the defects and qualities (of the goods), then he would be blessed in their transaction, and if they told lie or hide something, then the blessing of their transaction would be lost". ${ }^{8}$

Islam always encourages the trade and business but the business must run with fair intention by lawful (Halal) goods. If a person purchases and takes possession of an article and afterwards discovers it to have been defective at the time of sale, it is at his (buyer) option either to take it for the full price or to reject it. However, the buyer is not at his 
Doctrine of "Caveat Emptor" (Buyer be aware) in Common Law and the Doctrine of "Khiyar al aib" (Option of defect) in Islamic Law: A Comparative Study

liberty to retain the article and exact compensation on account of defect from the seller. ${ }^{9}$

In another occasion, it is narrated in Baihaqui, the Prophet said, "Whoever purchase a thing which he has not seen, has the option (of rejection) when he (buyer) sees it. ${ }^{10}$

Islam discourages to take advantages of the stupidity or simplicity of the purchaser and betray him by his (seller) active and intentional silence. Islamic teaching is different from the common law doctrine of caveat emptor. There is specific command of the Holy Prophet (Sm) against fraudulent transactions in sale. It is narrated from Abdullah Bin Umar (R), a person who cheated in sale was mentioned before the Prophet (sm). The prophet (sm) said "when you make a sale, say that there is no fraud in it". From this it is concluded that deception is not permitted in sale but it does not affect the validity of the sale except to the extent that it gives to the purchaser an option (whether to keep the property or to return it) when he comes to know about it. ${ }^{11}$ The duty of the seller is to inform the purchaser about the defects in goods is established by the traditions of the prophet (sm). He said, "One who cheats us, is not from amongst us". ${ }^{12}$ In sale it is lawful either for the seller or the buyer to impose a stipulation for not more than three days and one of the parties can cancel the contract of sale within that three days. ${ }^{13}$ Where there is defect in goods and it is unknown to either party, the principle of Khiyar al aib will be applied to them also.

\section{General principles guiding the doctrine of caveat emptor and Khiyar al aib}

\section{1: Principles of caveat emptor in Common Law}

Section 16 of the Sale of Goods Act, $1930^{14}$ incorporates the rule of caveat emptor as follows:

"Subject to the provisions of this Act and of any other law for the time being in force, there is no implied warranty or condition as to the quality or fitness for any particular purpose of goods supplied under a contract of sale".

It means the seller is not bound by law to supply the goods which are fit for any particular purpose or possess any particular quality. "It was 
for the buyer to make himself acquainted with qualities and defects of the goods which he contemplated purchasing". ${ }^{15}$

The exceptions of the principles which govern the doctrine of caveat emptor:

i. It is first and foremost obligation of the seller to allow the buyer to examine the goods to ensure its fitness.

ii. There is no implied understanding by the seller that he shall supply the goods as suit the buyer's purpose. ${ }^{16}$

iii. The seller is not bound to disclose every defect in the goods of which he may be cognizant.

iv. The seller is also under no duty to inform the buyer of his mistake in his inspection of quality of the goods to be sold.

\section{2: Principles of Khiyar al aib in Islamic Law:}

It is stated above that the doctrine of caveat emptor in common law is only allowing the buyer to inspect the goods to be purchased to confirm that the goods are free from any unknown defect (hidden) before conclusion of sale. On the other hand, the doctrine of Khiyar al aib in Islamic Law approves a general rule that the seller giving an access to examine the goods under an obligation to disclose the defect in goods before agreement in holding the justice in transaction.

The seller is under an absolute duty to disclose whatever the buyer asked him or not. Irrespective of any priority or ignorance of the buyer the seller is under the obligation to disclose the defects in goods. It is clear and imperative injunction for the seller to be confirmed himself that the thing is to be sold free from defect. The prophet (sm) himself discouraged to sell the goods without disclosing its defects.

"If any one sells defective goods without drawing attention to it to buyer, he (seller) will remain under Allah's anger or the angels will continue to curse him". ${ }^{17}$

In another hadith it has been narrated by Abdullah, Prophet (sm) said, "Allah's blessings on him who shows courtesy and patience in purchase to achieve his right". ${ }^{18}$ 
Doctrine of "Caveat Emptor" (Buyer be aware) in Common Law and the Doctrine of "Khiyar al aib" (Option of defect) in Islamic Law: A Comparative Study

It has been narrated by Hakim Ibn Hizam, Prophet (sm) said, "Both the parties in a sale have right to rescind the contract until they differ from each other. If they say true and inform the defect of goods, then for doing so, they will be blessed; but if they lie and hide the defect of goods, they are deprived from benefit". ${ }^{19}$ Regarding this Allah said, "O you, who believe, eat not each other's property by wrongful means". ${ }^{20}$

\section{3: Some general rules regarding khiyar al aib:}

i. A sale, without any stipulation, makes it necessary that the thing sold should be free from defect. ${ }^{21}$

ii. It is not lawful for a Muslim to sell anything to his brother and their remains a defect which he does not show him.

iii. The buyer should not have been aware of the defects at the time of agreement. ${ }^{22}$

iv. The option of inspection continues in the force to any distance of time even after the contract, unless destroyed by circumstances. ${ }^{23}$

v. The defect must still be in existence when the purchaser wishes to annul the contract; if the defect has disappeared the sale may not be dissolved. ${ }^{24}$

\section{Effects of caveat emptor on different goods:}

\section{1: Common law perspective:}

Under the Sale of Goods Act, $1930^{25}$ if the defects in goods are latent one which means the defect is not apparent on reasonable examination by any ordinary person, the buyer has a right to rescind the contract and claim damages even after conclusion of sale. ${ }^{26}$

Under Pure Food Ordinance, 1959, section $18 \& 19$ provide if the producer gives some wrong information or misled the buyer, shall be punished under section 44 for fine tk. 2 lakhs. ${ }^{27}$ The consumer's rights are protected under section 25(C) of the Special Powers Act, 1974 promulgating capital punishment for adulteration of foods and drink items which are likely harmful for human body. ${ }^{28}$ 


\section{2: Effects on insurance goods:}

To protect society from being harmed by defective products there are so many insurance companies which recognize insurance policy mainly by name of 'property insurance' and 'liability insurance'.

The meaning of the doctrine caveat emptor is the seller will not be liable for any loss of defective goods where he has given a chance to examine the goods. However, if such buyer has already entered into a property insurance policy, he may be protected from loss of defective goods shifting his liability to insurance company.

\section{3: Effects on stipulated goods:}

Stipulations have two parts, e.g. condition/guarantee and warranty. Such stipulations protect the buyer from loss of defective goods in the following ways:

i. A guarantee gives the aggrieved buyer for damages suffered and also can cancel the contract of sale as well. ${ }^{29}$

ii. In warranty violation by the seller, the buyer has only right to get damages without cancelling the contract of sale.

iii. Where the goods are sold by sample or on description, the bulk goods must correspond with the same and irregularities of which the buyer can get damages.

\section{4: Islamic doctrine of Khiyar Al Aib: How it protects the buyers' rights:}

Under Islamic shariah, the option of defect is a legal right; the buyer does not need to stipulate a reservation of the option at the time of contracting in order for him to be able to resort to it later. ${ }^{30}$ In Islam it is always an implied condition that any goods supposed to be sold free from any unknown defect and thus protecting the buyer's rights in the following ways:

i. The purchaser has an inherent right to inspect the goods before sale to confirm whether it is free from any defects. ${ }^{31}$

ii. If the goods, after being sold, should receive a further blemish in the hands of the buyer, and then buyer should after wards learn that it had also a blemish at the time of sale, he is entitled to receive compensation from the seller. ${ }^{32}$ 
Doctrine of "Caveat Emptor" (Buyer be aware) in Common Law and the Doctrine of "Khiyar al aib" (Option of defect) in Islamic Law: A Comparative Study

\subsection{1: On defective goods:}

It is always expected in Islamic transaction that the goods are free from known defects otherwise the buyer is entitled to compensation. Any buyer, under Islamic law, has an authentic implied warranty against the latent defects in goods purchased. ${ }^{33}$ It is narrated by Uqaba Bin Amir, Prophet (Sm) said, "It is illegal for one to sell a defective goods knowing it defective unless one informs the buyer to that effect". ${ }^{34}$ If a person purchases cloth and cut it up, and then before he had begun to sew it, discovers it to be defective he is in this case entitled to a compensation for the defect from the seller. ${ }^{35}$

\subsection{2: On Food Stuff:}

If a person purchases any article of food and eats, in that case, according to Hanafi Law, the buyer is not entitled to any compensation from the seller. But according to Shafei and Maliki disciples, the buyer is entitled to compensation. ${ }^{36}$

\subsection{3: On Insurance goods:}

At present day Islamic scholars have accepted the principles of insurance because the Shariah encourages helping one another with righteousness and piety. Islam permits those transactions which are based on mutual trade and commerce and free from riba, rishwah, maisir, gharah, and also free from unlawful subject matters e.g. Pig, wine, blood and others. Allah says, "Help ye one another in righteousness and piety" ${ }^{37} \mathrm{~A}$ buyer and his right is protected where the right of option of inspection is waived by inserting an exemption clause by the seller. The buyer who has an insurance policy may recover compensation from the insurance company. ${ }^{38}$

\section{Khiyar al aib: its importance and justifications:}

No doctrine is a doctrine unless its output helps to build a society with justice. The Islamic doctrine Khiyar al aib is based on equity and justice in the arena of trade and commerce and ensuring the justice in the following ways:

i. It is the seller's duty to allow the buyer to examine the goods before sale and the seller is not at liberty to remain silent giving the buyer an opportunity to examine. Regarding this Prophet (sm) said, It is narrated from Hakim Bin Hizam the 
apostle said, "the seller and the buyer have the right to keep or return the goods so long as they have not parted or till they apart; and if both the parties spoke the truth and described the defects and qualities of the goods, then they would be blessed in their transaction, and if they told lie or hide something, then the blessings of their transaction would be lost". 39

ii. The importance and objectives of transaction in Islam is to create a mutual relation between the parties and if there is honesty and transparency both parties can enjoy maximum benefit in here and herein after. Regarding this Allah says, "The Most High interdicted taking the money of others illegally, and commanded that trading should be conducted with mutual consent". 40

iii. In order to ensure fair transaction Prophet encouraged the presence of both parties before entering into agreement (of sale). It is reported that the Prophet ( $\mathrm{sm}$ ) saw someone selling food stuff. He put his hand in it and found it wet, he then said, "he who cheats us is not one of us". 41

\section{Guarantee and Warrantee: Protection of consumer's rights:}

\section{1: Common law doctrine caveat emptor and the protection of consumer's rights and safety:}

i. Section 13 of the Sale of Goods Act, 1930 provides as where there is a contract for sale of goods by description, there is an implied term that the goods will correspond with the description.

ii. The interest of the buyer is protected where the contract of sale depends on uberrimae fidie (utmost good faith); law imposes a duty on the seller to disclose all defects because one party is in a strong position to know the truth.

iii. The purchaser is protected where there is misrepresentation from the seller or where the buyer communicates his specific purpose of goods and he relies on seller's judgment.

\section{2: Khiyar al aib: How far is protecting consumer's rights:}

To ensure the transparency in transaction especially in purchasing, the seller is under an obligation to communicate the defects known to the 
Doctrine of "Caveat Emptor" (Buyer be aware) in Common Law and the Doctrine of "Khiyar al aib" (Option of defect) in Islamic Law: A Comparative Study

seller. However, the safeguard of the buyer under Islamic doctrine are as follows:

i. Islamic injunction makes it clear that if the defect in goods reduces the conventional market price or makes it unfit to use, the buyer can exercise his option. The Prophet (sm) said, "A muslim is a brother to another muslim, so it is illegal for him to sell to his brother a deficient thing unless he makes it clear to him (before sale). ${ }^{42}$

ii. If a purchaser purchases and takes possession of goods and afterwards discovers it to have been defective at the time of sale, the purchaser is capable to exercise his options. ${ }^{43}$

iii. It is not generally a requirement that the defect must be hidden in order to give rise to the option to cancel the contract; defect may be readily apparent, but the majority of the jurists hold that the buyer must not have known of, or noticed that defect at the time of the contract. ${ }^{44}$

\section{Conflicts and Findings:}

In common law, under the doctrine of caveat emptor the seller is only under a duty to allow the buyer to inspect the goods himself and nothing more. ${ }^{45}$ On the other hand, the Islamic doctrine of Khiyar al aib, if there is any defect discovered even after conclusion of sale; the buyer may exercise his options.

1. Under common law, the buyer has no remedy where option of inspection was given to him before sale; but under Islamic principle the buyer may annul the contract even after conclusion of sale if he finds the goods defective. ${ }^{46}$

2. Under common law, the buyer is personally liable for his careless or unskilled judgment; but under the Islamic doctrine after completion of sale, if it appears that the goods is defective or it is not suitable for buyer's purpose, he may get compensation. $^{47}$

3. It is common in both common and Islamic law that the seller will give a chance to buyer to examine the goods before sale. To this effect the Prophet (sm) said, "If any one sells a defective article without drawing attention to it, the seller will remain under Allah's anger or the angels will continue to curse him". ${ }^{48}$ 
4. In common law under section 4 of The Sale of Goods Act, 1930 in a sale the ownership is transferred immediately, so the buyer cannot return the goods or claim any damages if any stipulation was not given; but in Islamic law the buyer has the option. Prophet (sm) said, "Both the seller and the buyer have the option of cancelling and confirming a bargain unless they separate or the sale is optional". ${ }^{49}$

\section{Conclusion:}

The modern trend to protect consumer's right has minimized the importance of rule of caveat emptor because the rule was originated at a time when the goods were mostly sold in market overtly and the buyer, therefore, had every opportunity to inspect as to the quality of the goods. At present time most of articles are packed and sealed by producer but still the buyer can examine the packed goods, their descriptions shown on the cover, expire date, brand, logo etc.

Considering the comparison between two doctrines of two different dimensions it is justified to summarize that though both doctrines protect the buyer's interest but Islamic doctrine of Khiyar al aib is more potential to protect the society from contemporary problems in transactions. The reasons for justifications are:

i. The seller prior to an agreement to sale should notify the buyer of defects of the goods to be sold.

ii. The buyer should be allowed, before entering into the contract, to inspect the goods to be purchased so as to ensure it is free from any defect; and if the buyer is unable to do so as such wisely or correctly, the seller himself should assist him in doing so. The buyer must have given the right, after the transaction, to reject the purchased goods if the same is found to be defective while in the hands of the seller.

iii. A purchaser discovering the defect in the article purchased is at liberty to return it to the seller.

iv. A purchaser is entitled to compensation for defect discovered after the article has been consumed.

v. In the purchase of articles estimable by weight or by measure of capacity and the buyer afterwards discovers the article to be 
Doctrine of "Caveat Emptor" (Buyer be aware) in Common Law and the Doctrine of "Khiyar al aib" (Option of defect) in Islamic Law: A Comparative Study

in part defective, he is entitled, in that case, either to return the whole or to retain the whole.

vi. Islam does not permit any sort of cheating in transaction. So everybody is to avoid cheating at the time of buying and selling.

vii. Selling defective goods knowingly amounts to an unjust enrichment from seller's side, which is against the teaching of Islam. So Islamic principles are to be followed in every transaction.

\section{References}

1 Section 16 of the Act No. III of 1930, makes minor amendments in the Act were made by Sale of Goods Act (Amendment) Act, 1963 and it came into force on 26 March, 1971.

2 Hammilton, Charles, The Hedaya or guide of a commentary on the Mussaulman Laws, Premier Book House, Lahore, 1982,Vol.II, p.258.

3 Eastwood, R.A. The Contract of Sale of Goods, 2nd edition, Published in 1946, p. 42.

4 The decision of the Exchequer Chamber, page 79, published in "English Report", p. 03.

5 Baker, J.H. An Introduction to English Legal History, P. 138.

6 Dr. Niazi Khan, Liaqut Ali, Islamic Law of Contract, Lahore, Pakistan, p. 184.

7 Joseph Schacht, Origins of Muhammadan Jurisprudence, p. 160.

8 Dr. Khan, Md. Mohsin Shahih Al Bukhari, English translation,Darul Fikir Vol-III, p. 166.

9 Sircar, S. C. Al Sharai, Sunni and Imamia Codes, Vol-I, Law Publishing Company, Lahore, p.496.

10 Nujaim, IbnBahr-ur-Raiq, Vol-V, p.28.

11 Fathul Bari, Vol-IV, p.337.

12 Dr. Niazi Khan, Liaqut Ali Islamic Law of Contract,Lahore, Pakistan, p-197. 
13 Charles Hammilton, The Hedaya or guide of a commentary on the Mussaulman Laws , Premier Book House , Lahore, 1982,Vol.II Ch.II,p-248

14 Supra 1, sec 16.

15 Supra 3,p. 42

16 Kuchhal, M.C, Mercantile Law, Reader in commerce, University of Delhi, 5th revised edition 2004-2005, Vikas Publishing House Pvt. Ltd, New Delhi, p. 258

17 Ashraf, Md. Shah, IbnMajah, Vol-I, 1981, at p.613.

18 Huq, Azizul ,Maulana Sheikh Dhaka, 2010, Al Bukhari, Hadith No.1107 Vol-I to X, Sale-Buy Chapter, Alif Publications, p.267.

19 Ibid, Hadith No.1110. p. 268.

20 Al Quran 4:29.

21 Supra .6 p. 336

22 The Mejella, Art.340.

23 Supra. 2 p. 235

24 Haq, Masderai Sanhuri, ,Vol. IV, p-274.

25 Supra. 1 sec. 16

26 Supra. 16, p- 252.

27 Act LXVIII of 1959

28 Chowdhury, Huq Obaidul The Special Powers Act, Act XIV of 1974, 7th edition,2002 p.94

29 Supra.16, P. 247.

30 Dr. Rayner ,S.E, The Theory of Contracts in Islamic Law, a comparative analysis with particular reference to the modern legislation in Kuwait, Bahrain and the United Arab Emirates, 1st edition, 1991, p.327.

31 The Mejella, Art. 336

32 Supra. 2, p.259

33 Supra.31 Art. 336

34 Sahih Al Bukhari, No.292Vol- I to X, p.166

35 Supra. 2, ch.IV, p.260.

36 Ibid, p.261 
$37 \mathrm{Al}-$ Quran 5:2

38 The Mejella, op. cit. Art.343

39 Khan, Md. Mohsin Sahih Al Bukhari, English translation, p. 166; Dr. Khan, Ali Liaqut Islmaic Law of Contract, Lahore, Pakistan, p.185.

40 Al Quran, Sura An- Nisa, verse no.29.

41 Prof. Dr. Kharofa, Ala Eddin Transactions in Islamic Law, published by Noordeen, A.S. KL, 2nd edition,2000, p.120

42 Sanhuri, Masdar Al Haq, Vol-IV, p. 245

43 Supra. 2, Chapter. IV. P. 258

44 Supra. 30 page 330.

45 VenkatesaIyer, T.S. The Law of Contract, 5th edition, p. 100.

46 Supra.31 Art. 343.

47 Supra. 2, ch.IV, p. 258.

48 Sahih Miskat, Vol-III, p. 613

49 Supra 
IIUC Studies, Vol. 10 \& 11 